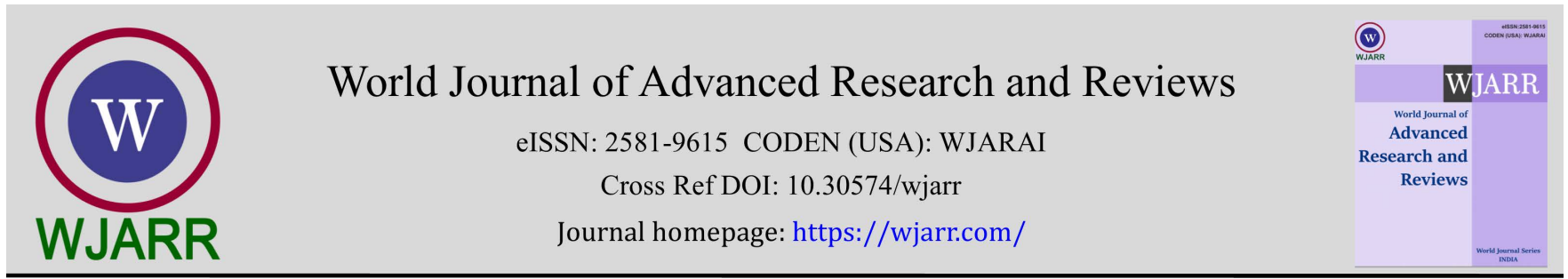

(RESEARCH ARTiCle)

Check for updates

\title{
Webinar's effect on nutritional knowledge to enhance immunity during COVID-19 pandemic
}

\author{
Intan Permata Sari 1, Fauziah Adhima 1, Ghivari Zuhal Fahmi 1, Ramidha Syaharani 1 and Widati \\ Fatmaningrum ${ }^{2, *}$
}

${ }^{1}$ Medical Program, Faculty of Medicine, Universitas Airlangga, Surabaya, Indonesia.

2 Department of Public Health, Faculty of Medicine, Universitas Airlangga, Surabaya, Indonesia.

World Journal of Advanced Research and Reviews, 2022, 13(01), 197-202

Publication history: Received on 30 November 2021; revised on 04 January 2022; accepted on 06 January 2022

Article DOI: https://doi.org/10.30574/wjarr.2022.13.1.0770

\begin{abstract}
Introduction: As of $31^{\text {st }}$ December 2021, there have been 4,262,540 confirmed cases of COVID-19, including 144,088 death cases in Indonesia. COVID-19 pandemic has affected the nutrition aspect, as an increasing number of undernutrition children also increases risk of obesity. Our group conducts webinars with the purpose of increasing public knowledge and awareness regarding general well-being: importance of adequate nutrition to increase immunity in the COVID-19 pandemic. The purpose of the study is to examine webinar participants' knowledge before and after webinar.
\end{abstract}

Method: The webinar conducted through a zoom meeting for 2 hours consists of 1 hour education and 1 hour question and answer session. The participants asked to fill a pretest before the webinar session and posttest after the webinar session. The results were statistically examined to determine the difference between pretest and posttest score.

Results: The webinar participant's demographic characteristics were dominated by 17-45 years old age group, high school graduates, and female participants. There is a significant difference $(\mathrm{p}<0.05)$ between pre and post-test score evaluated using Wilcoxon signed-rank test. After the webinar, there is a decreased number of participants with lowlevel nutritional knowledge from 31 to 23 participants.

Conclusion: There is an increase in knowledge about the importance of adequate nutrition to increase immunity in the COVID-19 pandemic from pre and post-test data. Thus, this webinar contributes to providing knowledge to participants in supporting the strengthening of socialization of adequate nutrition during COVID-19 pandemic.

Keywords: COVID-19; Diet; Immunity; Nutrition; Webinar

\section{Introduction}

Novel coronavirus severe acute respiratory syndrome coronavirus 2 (SARS-CoV-2) first found on 30 December 2019 in Wuhan, China and named as coronavirus disease 2019 (COVID-19) by World Health Organization (WHO) by 11 February 2020 [1]. The COVID-19 pandemic by now has been found all over the world. Globally, per 29 December 2021, there have been $281,808,270$ confirmed cases of COVID-19, including 5,411,759, reported to WHO. As of 27 December 2021, a total of 8,687,201,202 vaccine doses have been administered [2]. The first cases of COVID-19 in Indonesia were discovered on 2 March 2020 [3]. Presently as of 31 December 2021, there have been 4,262,540 confirmed cases of

\footnotetext{
${ }^{*}$ Corresponding author: Widati Fatmaningrum

Department of Public Health, Faculty of Medicine, Universitas Airlangga, Surabaya, Indonesia.

Copyright $(2022$ Author(s) retain the copyright of this article. This article is published under the terms of the Creative Commons Attribution Liscense 4.0.
} 
COVID-19, including 144,088 death cases. COVID-19 vaccination programs in progress, as of 160,012,443 first dose of vaccine have been administered [4].

The COVID-19 pandemic has been going on for over 1 year and its impact has affected various sectors: politics, education, economy, social, culture, and health. As in education, the traditional learning method characterized by classroom and outside the classroom teaching undergoes rapid shifts to online distance learning [5]. Students' mental health is also greatly affected as they experience anxiety and emotional disturbances [6]. The economic impact was expected to be severe, by increasing the poverty rate to $16.6 \%$ [7]. Tourism in Indonesia also experiences a crisis by decreasing tourist visits [8].

In the nutrition aspect, the COVID-19 pandemic could increase the possibility of obesity by curfew restrictions resulting in physical activities limitation while food intake has increased more than necessary [9]. By 2022, COVID-19 impact could result in an additional 9.3 million wasted children and 2.6 million stunted children, 168,000 additional child deaths, 2.1 million maternal anaemia cases, 2.1 million children born to women with a low body mass index (BMI). Pandemic-related economic disruption could increase household insecurity. Poor society has shifted to cheaper sources of calories such as starch and cereal. Consumption of nutrient-rich fruit, vegetables, dairy, and meat will decrease. Health service collapse accounts for a reduction in the coverage of essential nutrition programs (school feeding and micronutrient consumption). Stunting reduction program coverage and immunization are also affected by the limitation of mobilization and occupation of health services by COVID-19 patients [10].

Based on the evidence above, our group decided that education towards the community about general wellbeing is needed. We plan the program as a webinar entitled "Boosting Immune during a Pandemic through Food". The purpose of this webinar is to increase public knowledge and awareness regarding general well-being: the importance of adequate nutrition to increase immunity in the COVID-19 pandemic. The purpose of the study is to examine webinar participants' knowledge about the importance of adequate nutrition to increase immunity in the COVID-19 pandemic.

\section{Material and methods}

The webinar held on 3 July 2020 through a zoom meeting for 2 hours, consists of 1 hour of education and 30 minutes of question and answer session. The webinar was attended by 60 participants, they were asked to fill a pretest before the webinar session and posttest after the webinar session. The results were statistically analyzed to determine the difference between pretest and posttest scores. The education session presented by Dr. Widati Fatmaningrum dr., M.Kes., Sp.GK through PowerPoint slides. The main content of the slide is: 1) Explanation of the basic science of balanced nutrition, 2) Signs and symptoms of malnutrition and its effect on immunity, 3) The importance of maintaining nutrition for immunity during a pandemic, 4) Food ingredients that can increase immunity, and 5) How to maintain healthy body weight during a pandemic. The question and answer session was led by the moderator and the participants asked the question through zoom chat, raise hand feature, and directly.

We examined respondent characteristics by analyzing age, gender, and educational background characteristics. The pretest and posttest scores classified the level of participants' knowledge about diet and nutrition to optimize the immune system into low (<70), moderate (70-80), and high (90-100). The difference between pretest and posttest score was statistically examined by Wilcoxon signed-rank test if the distribution was not normal and Paired T-Test if the distribution was normal. We also compare the number of low, moderate, and high levels of knowledge before and after the webinar to examine if there is an increased/decreased number between each level.

\section{Results and discussion}

\subsection{Demographic Characteristics}

Only 52 out of 60 participants filled the pre-test and post-test completely. The demographic characteristics of webinar participants are summarized in table 1. Most of the participants were aged 17-45 years old (82.69\%) and graduated from high school (67.31\%). There were more female respondents $(78.85 \%)$ than the male counterpart $(21.15 \%)$. 
Table 1 Characteristics of Respondents by Gender and Age

\begin{tabular}{|l|c|c|}
\hline \multirow{2}{*}{ Respondent Characteristics } & \multicolumn{2}{l|}{ Respondent } \\
\cline { 2 - 3 } & F & $\%$ \\
\hline Age & 3 & 5.77 \\
\hline$<17$ years old & 43 & 82.69 \\
\hline $17-25$ years old & 3 & 5.77 \\
\hline $26-35$ years old & 1 & 1.92 \\
\hline $36-45$ years old & 2 & 3.85 \\
\hline $45-56$ years old & 11 & 21.15 \\
\hline Gender & 41 & 78.85 \\
\hline Male & \multicolumn{2}{|l}{} \\
\hline Female & 4 & 7.69 \\
\hline Educational background & 35 & 67.31 \\
\hline Middle school & 4 & 7.69 \\
\hline High School & 9 & 17.31 \\
\hline Associate degree & \multicolumn{2}{|l}{} \\
\hline Bachelor degree & \multicolumn{2}{|l}{} \\
\hline
\end{tabular}

\subsection{Nutritional Knowledge}

Participants' knowledge about the diet required to optimize the immune system was assessed and classified into low, moderate, and high based on the pre- and post-test scores. Table 2 shows the distribution of correct and wrong answers for the ten nutritional questions. The pretest means score was $61.54 \pm 19.14$ which is categorized into the low-level nutritional knowledge, while the post-test mean score is $69.42 \pm 19.55$ which still falls into low-level knowledge category. Based on Wilcoxon signed-rank test, there is a significant difference $(\mathrm{p}<0.05)$ between the pre- and post-test scores. After the webinar had ended, the number of participants with low-level nutritional knowledge decreased from 31 to 23. As many as 25 participants (48.08\%) had higher post-test scores than pre-test scores.

Table 2 Distribution of Knowledge Parameter regarding Diet for Optimizing the Immune System during Pandemic

\begin{tabular}{|l|c|c|c|c|}
\hline Parameter & \multicolumn{2}{|c|}{ Pre-test } & \multicolumn{3}{c|}{ Post-test } \\
\hline & $\begin{array}{l}\text { Correct } \\
\text { answer }\end{array}$ & $\begin{array}{l}\text { Wrong } \\
\text { answer }\end{array}$ & $\begin{array}{l}\text { Correct } \\
\text { answer }\end{array}$ & $\begin{array}{l}\text { Wrong } \\
\text { answer }\end{array}$ \\
\hline Definition of diet & 30 & 22 & 34 & 18 \\
\hline Classification of micronutrients and macronutrients & 24 & 28 & 26 & 26 \\
\hline Essential nutrients for immune system & 36 & 16 & 35 & 17 \\
\hline Pillars of balanced diet & 13 & 39 & 17 & 35 \\
\hline Definition of balanced diet & 41 & 11 & 48 & 4 \\
\hline Factors affecting daily energy requirement & 44 & 8 & 45 & 7 \\
\hline Normal BMI & 42 & 10 & 45 & 7 \\
\hline Natural source of vitamins & 48 & 4 & 50 & 2 \\
\hline Portion control for balanced diet & 15 & 37 & 24 & 28 \\
\hline Effects of malnutrition on immune system & 26 & 26 & 36 & 16 \\
\hline
\end{tabular}


Table 3 Descriptive Statistic of Pre-Test and Post-Test Score

\begin{tabular}{|c|c|c|c|c|c|c|c|c|}
\hline \multirow[t]{2}{*}{ Population } & \multicolumn{4}{|c|}{ Pre-Test } & \multicolumn{4}{|c|}{ Post-Test } \\
\hline & Min & Max & Mean & SD & Min & Max & Mean & SD \\
\hline \multicolumn{9}{|l|}{ Gender } \\
\hline Female & 10 & 100 & 61.46 & 19.69 & 30 & 100 & 68.05 & 20.03 \\
\hline Male & 30 & 90 & 61.82 & 17.79 & 50 & 100 & 74.55 & 17.53 \\
\hline \multicolumn{9}{|l|}{ Age } \\
\hline$<17$ years old & 50 & 80 & 66.67 & 15.28 & 40 & 60 & 50.00 & 10.00 \\
\hline $17-25$ years old & 20 & 100 & 62.09 & 17.80 & 30 & 100 & 70.47 & 19.51 \\
\hline 26-35 years old & 60 & 90 & 70.00 & 17.32 & 50 & 90 & 63.33 & 23.09 \\
\hline $35-45$ years old & 80 & 70 & 80.00 & - & 70 & 70 & 70.00 & - \\
\hline $46-56$ years old & 10 & 30 & 20.00 & 14.14 & 70 & 100 & 85.00 & 21.21 \\
\hline \multicolumn{9}{|c|}{ Educational background } \\
\hline Middle school & 50 & 80 & 62.50 & 15.00 & 40 & 60 & 50.00 & 8.17 \\
\hline High school & 20 & 100 & 63.14 & 18.11 & 30 & 100 & 69.43 & 19.84 \\
\hline Associate degree & 10 & 60 & 40 & 21.60 & 50 & 100 & 72.50 & 20.62 \\
\hline Bachelor degree & 30 & 90 & 64.44 & 20.68 & 50 & 100 & 76.67 & 18.03 \\
\hline Total & 10 & 100 & 61.54 & 19.14 & 30 & 100 & 69.42 & 19.55 \\
\hline
\end{tabular}

Table 4 Result of Wilcoxon Signed-Rank Test for Pre-Test and Post-Test Score

\begin{tabular}{|l|c|c|c|c|c|c|}
\hline \multirow{2}{*}{ Level of knowledge } & \multirow{2}{*}{ Pre-test } & \multirow{2}{*}{ Post-test } & \multicolumn{3}{|c|}{ Rank } & \multirow{2}{*}{ P } \\
\cline { 4 - 6 } & & & Negative & Positive & Ties & \\
\hline Low & 31 & 23 & 9 & 25 & 18 & 0.003 \\
\hline Moderate & 15 & 15 & & & & \\
\hline High & 6 & 14 & & & & \\
\hline Mean & 61.54 & 69.42 & & & \\
\hline
\end{tabular}

\section{Discussion}

In this pandemic era, education about nutrition is very necessary. Although no food supplement can prevent or cure COVID-19 infection, nutrition is one of the important aspects that can influence the immune system to fight infection. In addition, the consumption of good nutrition will also reduce the risk of other health problems such as obesity, heart disease, diabetes and some types of cancer [11].

In this webinar, all participants were asked to fill out a pre-test before the webinar session and a posttest after the webinar session. Based on the Wilcoxon signed-rank test, there is a significant difference $(\mathrm{p}<0.05)$ between the pre- and post-test scores. The pre-test mean score was $61.54 \pm 19.14$ which is categorized into low-level nutritional knowledge, while the post-test mean score is $69.42 \pm 19.55$ which still falls into low-level knowledge category. The low-level nutritional knowledge in the pre-test was possible because the participants had never received nutrition education before. However, after the webinar ended, there was an increase in the average post-test scores compared to the pretest scores, but it was still in the low-level nutritional knowledge category. This may be related to the educational status of the participants, which were dominated by high school students. In accordance with previous study which states that 
nutritional knowledge of Kuwaiti high school students was not only low but also may lead to unhealthy futuristic prospects [12].

A person's level of education is related to a person's level of health. The higher a person's education level, the easier it is to accept the concept of healthy living including the nutritional aspect independently, creatively, and sustainably [13]. This is similar to the results of this webinar, which illustrates that the higher a person's education level, the higher an average post-test score obtained.

According to Irnani \& Sinaga [14], the low level of nutritional knowledge can be caused by several factors, including internal factors, external factors, and technical factors. Internal factors that can affect nutritional knowledge include physical and psychological aspects of participants who differ between individuals. The physical aspect includes the condition of the senses, physical health, and limbs when attending this webinar, while the psychological aspect includes the level of intelligence, disposition, emotional state, willpower, fantasy power, and logic. External factors that can affect the level of nutritional knowledge come from the surrounding environment such as noise factors, room conditions (light, temperature, smell), and people or objects around that disturb the participant's concentration when doing pre-test and post-test about nutritional knowledge. The technical factor is related to the method of delivering nutrition material, in which this webinar is carried out with a limited duration.

Increased scores of the post-test results showed that the material presented was sufficiently understood by the participants. When viewed from each question, in general, there is an increase in the number of correct answers in the post-test. Gegenfurtner \& Ebner [15] explained the effectiveness of webinars can be assessed in several ways, one of which can be assessed in terms of participants' development from pretest to posttest, measuring their relative increase in knowledge and skills. However, participants developed more knowledge and skills from pretest to posttest if the webinar duration was longer. This positive association between duration and learning seems intuitive because participants had longer exposure and thus more time to develop their knowledge and skills. But, the duration of the webinar must be adjusted to the target participants. The webinars usually run from 60 to 120 minutes [16]. If the duration is longer, it is feared that participants, especially the general public, will be bored so they cannot concentrate on listening to the material presented [17]. When the webinars prolonged 90 minutes, the participants were started to leave [18]. This is different from the webinar in higher education and professional training, which is considered more effective if it is carried out in a single webinar with a long duration than in a repeated webinar [15].

To increase the public's nutritional-knowledge level, additional education using other media is needed. According to Jatmika et al [19], health promotion media are classified into three types, namely print media such as booklets, leaflets, rubik's and posters; electronic media such as video; and outdoor media such as billboards and banners. In principle, the more senses involved in receiving messages and health information from a media, the easier it will be for recipients to understand it. Dissemination of this information can be done online through social media. According to Sampurno, Kusmuandyoko, and Islam [20], social media culture in Indonesia can act as a teacher who is able to educate the public regarding COVID-19 because it is able to provide opportunities for indirect individual interactions.

\section{Conclusion}

There is an increase in knowledge about the importance of adequate nutrition to increase immunity in the COVID-19 pandemic from pre and post-test data. Thus, this webinar contributes to providing knowledge to participants in supporting the strengthening of socialization of adequate nutrition during the COVID-19 pandemic.

\section{Compliance with ethical standards}

\section{Acknowledgments}

The authors would like to thank Faculty of Medicine, Universitas Airlangga for supporting this study.

\section{Disclosure of conflict of interest}

The authors declare that no conflict of interest might intervene with the result of this study.

\section{Statement of informed consent}

Informed consent was obtained from all participants involved in present study. 


\section{References}

[1] Seyed Hosseini E, Riahi Kashani N, Nikzad H, Azadbakht J, Hassani Bafrani H, Haddad Kashani H. The novel coronavirus Disease-2019 (COVID-19): Mechanism of action, detection and recent therapeutic strategies. Virology. August 2020; 551: 1-9.

[2] WHO. WHO Coronavirus (COVID-19) Dashboard [Internet]; (C) 2021 [cited 2021 July 30]. Available from https://covid19.who.int/.

[3] Nugraha B, Wahyuni L, Laswati H, Kusumastuti P, Tulaar A, Gutenbrunner C. COVID-19 pandemic in Indonesia: Situation and challenges of rehabilitation medicine in Indonesia. Acta Med Indones. 2020; 52(3): 299-305.

[4] Satgas COVID-19. Peta Sebaran [Internet]; (C) 2021 [cited 2021 July 30]. Available from https://covid19.go.id/peta-sebaran-covid19.

[5] Abidah A, Hidaayatullaah HN, Simamora RM, Fehabutar D, Mutakinati L. The impact of covid-19 to Indonesian education and its relation to the philosophy of "Merdeka Belajar." Stud Philos Sci Educ. 2020; 1(1): 38-49.

[6] Irawan A, Lestari M, Dwisona D. Psychological impacts of students on online learning during the pandemic COVID-19. KONSELI J Bimbing dan Konseling. 2020; 7(1): 53-60.

[7] Suryahadi A, Al Izzati R, Suryadarma D. Estimating the impact of covid-19 on poverty in Indonesia. Bull Indones Econ Stud. 2020; 56(2): 175-92.

[8] Atmojo M, Fridayani H. An assessment of covid-19 pandemic impact on Indonesian tourism sector. J Gov Public Policy. 2020; 8(1): 1-9.

[9] Yilmaz H, Aslan R, Unal C. The effect of the COVID-19 outbreak on eating habits and food purchasing behaviors of university students. Kesmas Natl Public Heal J. 2020; 15(3).

[10] Osendarp S, Akuoku J, Black R, Headey D, Ruel M, Scott N, et al. The COVID-19 crisis will exacerbate maternal and child undernutrition and child mortality in low- and middle-income countries. Nat Fod. 2021; 2(7): $476-84$.

[11] WHO. \#HealthyAtHome [Internet]; (C) 2021 [cited 2021 July 30]. Available from https://www.who.int/campaigns/connecting-the-world-to-combat-coronavirus/healthyathome.

[12] Al-Isa AN. Nutritional knowledge among high school male students in Kuwait. J Community Med Health Educ. 2018; 08(05).

[13] Prayitno FF, Angraini DI, Himayani R, Graharti R. Hubungan pendidikan dan pengetahuan gizi dengan status gizi ibu hamil pada keluarga dengan pendapatan rendah di Kota Bandar Lampung. J Medula. 2019; 8(2): 225-9.

[14] Irnani H, Sinaga T. Pengaruh pendidikan gizi terhadap pengetahuan, praktik gizi seimbang dan status gizi pada anak Sekolah Dasar. J Gizi Indones (The Indones J Nutr. 2017; 6(1): 58-64.

[15] Gegenfurtner A, Ebner C. Webinars in higher education and professional training: a meta-analysis and systematic review of randomized controlled trials. Educ Res Rev. 2019; 28: 100293.

[16] Ali SR, Dobbs TD, Whitaker IS. Webinars in plastic and reconstructive surgery training-a review of the current landscape during the COVID-19 pandemic. J Plast Reconstr Aesthetic Surg. 2020; 73(7): 1357-404.

[17] Gegenfurtner A, Zitt A, Ebner C. Evaluating webinar-based training: a mixed methods study of trainee reactions toward digital web conferencing. Int J Train Dev. 2020; 24(1): 5-21.

[18] Tanidir Y, Gokalp F, Akdogan N, Batur AF, Sekerci CA, Egriboyun S, et al. How did the COVID-19 pandemic affect audience's attitudes in webinars? Int J Clin Pract. 2021; 14239.

[19] Jatmika SED, Maulana M, Kuntoro, Martini S. Pengembangan Media Promosi Kesehatan. Buku Ajar. $2019 ; 271$.

[20] Sampurno MBT, Kusumandyoko TC, Islam MA. Budaya media sosial, edukasi masyarakat, dan pandemi COVID19. SALAM J Sos Dan Budaya Syar-I. 2020; 7(5): 529. 